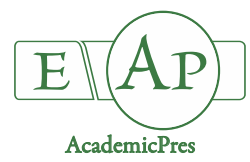

\title{
Lithothamnion calcareum Nanoparticles Increase Growth of Melon Plants
}

\author{
Andreia M.P. NEGREIROS ${ }^{1}$, Rui SALES JÚNIOR ${ }^{1 *}$, \\ Francisco F. MAIA JÚNIOR ${ }^{1}$, Rodolfo B. SILVA ${ }^{2}$, José A.P. COSTA², \\ Erika V. MEDEIROS ${ }^{3}$ \\ ${ }^{1}$ Universidade Federal Rural do Semi-Arido, Centro de Ciências Agrárias, 59625-900 Mossoró, Rio Grande do Norte, \\ Brazil;deia_mitsa@hotmail.com;jrrui@hotmail.com(“correspondingauthor);maiajr@ufersa.edu.br \\ ${ }^{2}$ Universidade Estadual do Rio Grande do Norte, Laboratório de Física, 59610-090 Mossoró - Rio Grande do Norte, \\ Brazil; rodolfo.bezerra@hotmail.com; alzamir@ymail.com \\ ${ }^{3}$ Universidade Federal Rural de Pernambuco, Departamento de Agronomia, 52171-000, Garanhuns, Pernambuco, Brazil; evmbio@gmail.com
}

\begin{abstract}
The application of alternative fertilizers to the soil in a sustainable way in order to supply nutrients to plants is important for growers and for the environment. Calcareous algae, Lithothamnion calcareum (Lit), is considered an alternative fertilizer because it is rich in nutrients, particularly magnesium and calcium, that are essential for plants. The objective of this study was to investigate the effect of different formulations, doses and fertilization intervals of $L$. calcareum on growth of melon plants. Two experiments were performed. The first experiment aimed to evaluate the effect of various formulations and doses of Lit on the growth of melon plants. The second experiment was carried out to evaluate the use of formulations and fertilization intervals of Lit. Formulations and doses of Lit had a significant effect on the efficiency in the development of melon plants. No impact was observed when using a concentrated suspension of Lit. However, four applications of Lit nanoparticle formulations every 7 days increased the growth of melon plants at doses close to $1 \mathrm{~kg} \mathrm{ha}^{-1}$. We provide the first data related to beneficial effects on melon growth of $L$. calcareum, in different formulations, application intervals and doses, applied to red-yellow soil.
\end{abstract}

Keywords: application intervals; calcareous algae; Cucumis melo; fertilizer; formulations; powder-micronized

\section{Introduction}

Calcareous algae have been used over time as corrective material on the French, English and Irish coasts to correct the acidic and/or calcium deficient soils. In these regions, the product is known as "Calcified Seaweed" or "Mäerl". Ancient studies report its use since 1186 (Le Bleu, 1983). France is the world's largest producer of bioclastic and lithoclast granulates for industrial use (Dias, 2000).

In Brazil a large continental shelf of North-Northeast limestone algae was discovered in the 1960's by researchers from the Oceanographic Institute of the Federal University of Pelotas. According to Kempf (1974), the potential exploration of the platform is comparable to the French "Mäerl".

Subsequent studies showed that the Brazilian continental zone represents an extensive coverage of carbonate sediments, extending from the Pará River (Lat. $00^{\circ} 30$ 'S) to Rio Grande do Sul (Cavalcanti, 2011). This shelf presents deposits of algae with higher potential for economic exploitation than the French deposits. Among the different bioclastic materials found, sediment deposits formed by fragments of coral algae predominate, mainly of the genus Lithothamnion (Dias, 2000).

Lithothamnion calcareum (Pallas) Areschoug is a kind of seaweed of the Rhodophyta phylum, belonging to the order Corallinales of the family Lithothamniaceae. It has a red coloration and in its cell walls precipitate Calcium Carbonate $\left(\mathrm{CaCO}_{3}\right)$ and Magnesium $(\mathrm{Mg})$ in the form of crystals of calcite, being a simple organic product (Woelkerling, 1985; Graham et al., 2008; Guiry and Guiry, 2017).

Lithothamnion calcareum has been used in different ways as animal nutrition (Carlos et al., 2011; Ucrós et al., 2012; Hagg et al., 2013; Lopes et al., 2013; Schlegel and Gutzwiller, 2017), herbal medicines (Goetz, 2008), biopolymers (Thangavelu and Subramani, 2016) and cosmetics (Dias, 2000). In agriculture, L. calcareum products have been applied as fertilizers and soil acidity 
brokers (Melo and Furtini Neto, 2003; Goetz, 2008; Costa Neto et al., 2010). The use of $L$. calcareum in agriculture is characterized by the high proportion of Calcium $(\mathrm{Ca})$ and Magnesium (Mg), essential elements for plants (Souza et al., 2007; Evangelista et al., 2013).

Studies reported by Filgueira (2008) showed that even in the face of cultural practices such as liming, the demand for calcium is not always sufficient to adequately supply the needs of plants. Therefore, the use of this alga may be a technology applied by the producers in planting or coverage to minimize symptoms of deficiencies of $\mathrm{Ca}$ and $\mathrm{Mg}$ in the field.

Although L. calcareum is widely used in different sectors of the world economy, its use in agriculture has been used increasingly in the last 20 years in Brazil. According to Kempf (1974), L. calcareum contains $\mathrm{Ca}=32 \%, \mathrm{Mg}=2 \%$, $\mathrm{S}=0.2 \%, \mathrm{Cl}=0.2 \%, \mathrm{Mo}=0.0005 \%$ and $\mathrm{Fe}=0.1 \%$, which makes it a viable option in regions close to the coast, as a source of nutrition and soil correction.

Studies have shown that the use of this alga was efficient in the formation of seedlings in yellow passion fruit (Passiflora edulis Sims f. flavicarpa Deneger) (Mendonça et al., 2006); in papaya (Carica papaya L.) (Hafle et al., 2009; Teixeira et al., 2009); in the development of 'Swingle' citrus (Citrus paradisi Mac $\times$ Poncirus trifoliata L. Raf.) (Araújo et al., 2007) and 'Cleopatra' mandarin (Citrus reticulata Blanco var. 'Cleópatra') (Cruz et al., 2008); in the increase of coffee productivity (Coffea arabica L.) (Evangelista et al., 2013) and red pitaya [Hylocereus undatus (Haw.) Britton \& Rose], as well as increasing the quality of the fruits produced (Costa et al., 2015).

Although some studies demonstrate the importance of the use of this alga, there are still gaps regarding its use in soils used for melon cultivation. Its study is important as a tool to provide organic inputs for the management of this group of crops. Heretofore, there is no report of the use of this seaweed in melon culture (Cucumis melo L.), which makes this a pioneering work in this context. Due to the scarcity of information on the efficiency of L. calcareum in the development of melon plants, the objective of the present study was to evaluate the effect of different formulations, doses and application intervals of $L$. calcareum on the growth of melon plants.

\section{Materials and Methods}

Algae sources

Lithothamnion calcareum algae (Lit) were obtained as a commercial product Primaz (PrimaSea, Brazil) and showed the following chemical properties: Calcium $(\mathrm{CaO})=46 \%$; Magnesium $(\mathrm{MgO})=4.2 \%$ and Silica and insoluble $=$ $16.25 \%$

\section{Formulations of Lithothamnion calcareum}

Different formulations of Lit were used: concentrated suspension (CS), powder-micronized (PM) and nanoparticles (nano). The nano was obtained by milling the PM formulation to obtain sizes between 100 and $240 \mathrm{~nm}$ in a planetary type ball mill (Fritsch, pulverisette $7 "$ ).
The high energy milling process was performed at room temperature in a $45 \mathrm{~mL}$ tungsten carbide container containing four spheres, also of the same material, each with a $15 \mathrm{~mm}$ radius and a mass of $25 \mathrm{~g}$. The weight ratio of the ball to the powder was maintained at 10:1. The grinding was carried out at a rotation rate of 300 RPM, for a period of $20 \mathrm{~h}, 25 \mathrm{~g}$ of the product being processed by milling.

\section{Soil and seed preparation}

The experiment was conducted in red-yellow, eutrophic, abrupt and sand-free sandstone, collected in a semiarid region in Rio Grande do Norte State, Brazil, showing the following chemical characteristics: $\mathrm{pH}\left(\mathrm{H}_{2} \mathrm{O}\right)=7.0$; $\mathrm{MW}=$ $0.26 \% ; \mathrm{P}=210 \mathrm{mg} \mathrm{dm}^{-3} ; \mathrm{K}=0.43 \mathrm{cmol} \mathrm{dm}^{-3} ; \mathrm{Na}=0.15$ $\mathrm{cmol} \mathrm{dm}{ }^{-3} ; \mathrm{Ca}=3.3 \mathrm{cmol} \mathrm{dm}^{-3} ; \mathrm{Mg}=1.8 \mathrm{cmol} \mathrm{dm}^{-3} ; \mathrm{Al}=$ $0.00 \mathrm{cmol} \mathrm{dm}^{-3}$ (Santos et al., 2013). Soil was sterilized by autoclaving for $50 \mathrm{~min}$ at $121^{\circ} \mathrm{C}$ and $1.2 \mathrm{ATM}$ pressure in order to eliminate possible phytopathogenic agents.

The commercial substrate Tropstrato $\mathrm{HT}^{\oplus}$ from 'Vida Verde' was also used, with the following characteristics: humidity $=60 \% \mathrm{w} / \mathrm{w}$, water retention capacity $=130 \% \mathrm{w}$ $/ \mathrm{w}$, dry base density $=200 \mathrm{~kg} \mathrm{~m}^{-3}$, wet basis density $=500$ $\mathrm{kg} \mathrm{m}^{-3}$ and $\mathrm{pH}=5.8$.

Plastic pots containing two previously disinfected melon seeds of yellow melon cv. 'Gladial', from Rijk Zwaan, were used in both experiments. All irrigations were carried out with a manual irrigator, with a daily irrigation shift, aiming to keep the substrate always close to the field capacity.

Two experiments were carried out in a greenhouse (5'11'15" S and $37^{\circ} 20^{\prime} 39^{\prime \prime} \mathrm{W}, 18 \mathrm{~m}$ altitude), with a BSh (hot semi-arid climate), according to Köppen's classification (Alvares et al., 2013).

\section{Experiment I: Growth of melon in different formulations} and doses of L. calcareum

This experiment was conducted in a completely randomized manner, consisting of eight treatments and five replicates, which were: CONT-control; Lit CS (doses 10, 20 and $30 \mathrm{~L} \mathrm{ha}^{-1}$ ); Lit nano (doses 1.0, 5.0 and $10 \mathrm{~kg} \mathrm{ha}^{-1}$ ) and Lit PM at the dose of $50 \mathrm{~kg} \mathrm{ha}^{-1}$, respectively. All doses were calculated with 12,500 plants per hectare as the reference value.

Plastic pots with $500 \mathrm{~mL}$ capacity were filled with the Tropstrate HT substrate. Melon seeds were applied two per pot at distances equidistant from the edges. Seven days after sowing, one plant per pot (replicate) was left.

At 15 days after sowing, the following variables were evaluated: plant height $(\mathrm{cm})$, root length $(\mathrm{cm})$, fresh and dry weight of shoot $(\mathrm{g})$, fresh and dry weight of root $(\mathrm{g})$. The plant height $(\mathrm{H})$ was determined by measuring the height from plant crown to the apical meristem; root length (RL) was obtained by measuring the plant crown to the end of the primary root. A 'BL-3200-H' electronic scale of the 'Shimadzu' brand was used to measure the variables: shoot fresh matter (SFM) and root fresh matter (RFM). After the shoot, fresh matter (SFM) and root dry matter (RDM) were obtained by individually placing samples in previously weighed paper bags and drying in an oven with forced air circulation at $65^{\circ} \mathrm{C}$ for a period of 72 hours, until reaching constant dry matter. The samples were then weighed on an analytical balance to obtain the dry weight of the root. 
428

The data was submitted to analysis of variance. For the qualitative levels, orthogonal contrasts were constructed and the Scheffé test with $5 \%$ of significance was applied, aiming at the comparison between the treatments and those with the witnesses by ASSISTAT (Silva and Azevedo, 2016). For the quantitative levels the adjustment of regression modelling was performed using the curve adjustment program "Table Curve".

Experiment II: Melon growth in different formulations and application intervals of L. calcareum

The experimental design was completely randomized and distributed using a $3 \times 3+1$ factorial scheme. It included three formulations of $L$. calcareum (CS, PM and Nano); and three application intervals $(7+7+7+7$, $10+10+10$ and $14+14$ days of application) plus the control, with four replications. All experiments were repeated.

Plastic pots (1 kg capacity) were filled with a mixture of autoclaved soil, quartz sand, and the commercial substrate Tropstrato HT, in a ratio of $1: 1: 1$.

Melon seeds were sown chopped. Subsequently, the same applications were carried out as in the treatments of experiment I.

The data was submitted to analysis of variance (ANOVA) by ASSISTAT (Silva and Azevedo, 2016). The Tukey test $(\mathrm{P} \leq 0.05)$ was applied in cases where the treatment data presented significant differences according to the $\mathrm{F}$ test at $\mathrm{P} \leq 0.01$ and $\mathrm{P} \leq 0.05$ probability levels.

\section{Results and Discussion}

Experiment I: Growth of melon in different formulations and doses of L. calcareum

The application of different formulations and doses of L. calcareum was efficient $(\mathrm{P}<0.05)$ in the development of melon plants (Figs. 1 and 2). The analysis of the orthogonal contrasts indicates a significant effect at $\mathrm{P}<0.05$ among the different Lit formulations (CS, PM and nano) for most of the variables analyzed in the different contrasts (Table 1 ). In the case of contrast $\hat{y} 1$ (control vs other treatments), the treatments in which Lit was applied showed more efficiency in relation to the control for $\mathrm{H}, \mathrm{RL}$ and $\mathrm{RFM}$ of melon plants. The same effect was found for contrast $\hat{y} 2$ (Lit CS vs Lit nano), in which all variables were significant $(\mathrm{P}<0.05)$, except for RL (Table 1).

The SFM, RL, RFM and RDM of melon plants showed significant effects in the case of contrast $\hat{y} 3$ (Lit CS vs Lit $\mathrm{PM}$ ). However, the $\mathrm{H}$ of melon showed no difference between the formulations tested. Contrast $\hat{y} 4$ (Lit nano vs Lit PM) presented a significant difference in four variables $\mathrm{H}, \mathrm{RL}, \mathrm{RFM}$ and RDM, which displayed increases of 15.3, 23.9, 31.3 and $125 \%$, respectively (Table 1 ).

There was no impact $(\mathrm{P}<0.05)$ of Lit CS application on the soil when comparing $\mathrm{H}$ and SFM because the maximum value was observed at 0 dose (Fig. 1). However, doses of 16, 6 and $20 \mathrm{~L} \mathrm{ha}^{-1}$ give maximum values to the variables RL, RFM and RDM, of $40.67 \mathrm{~cm}, 2.33 \mathrm{~g}$, and $0.078 \mathrm{~g}$ respectively. The increases observed in these variables were probably due to the chemical and biological improvement behaviour with the application of $L$. calcareum in the substrate. According to Dias (2010), calcareous algae contribute to a more permeable soil and condition the effectiveness of the clay-humic complex, causing direct effects on the soil by increasing the nutrient absorption and improving soil structure, which allows greater root penetration and distribution. These factors contribute to production, productivity and quality of various crops. Here, plants that received Lit showed different results when applied in different formulations.

Melon plants treated with the Lit nano formulation increased H, RL, SFM, RFM and RDM (Fig. 2). Lit nano applied at doses of $1.2 ; 5.2 ; 1.2 ; 3.12$ and $1.0 \mathrm{~kg} \mathrm{ha}^{-1}$ showed maximum RDM values of $17.88 \mathrm{~cm}$ of $H$; $44.76 \mathrm{~cm}$ of RL; $3.72 \mathrm{~g}$ of SFM; $3.12 \mathrm{~g}$ of RFM and $0.1 \mathrm{~g}$, respectively (Fig. $2)$. These results suggest that $L$. calcareum in the nanoparticle formulation exerts a corrective action on the acidity of the substrate. Corroborating with the present study, Melo and Furtini Neto (2003) showed that the application of Lit improved nutrient assimilation, supporting the growth of the root system of melon plants, rather than that of the aerial part, when plants were treated in the CS formulation.

Increasing the dose of Lit in the nano formulation followed the same behaviour as Lit CS, which showed a reduction in the growth of melon plants with increasing dose (Fig. 2). Similar results were observed by Teixeira $e t$ al. (2009) when using doses of $L$. calcareum superior to $2 \mathrm{~kg}$ $\mathrm{m}^{-3}$ in the production of papaya seedlings. This can be explained by the fact that high doses of the product may cause an imbalance in the cation ratios, resulting in possible phytotoxicity.

In all treatments with Lit nano application, the values of $\mathrm{H}, \mathrm{SFM}, \mathrm{RFM}$ and RDM were higher than those of the control. The highest $\mathrm{H}$ value for melons was recorded with Lit nano at $1.2 \mathrm{~kg} \mathrm{ha}^{-1}$. This dose was the maximum SFM point with $3.72 \mathrm{~g}$ (Fig. 2C). Melon plants developed better when Lit nano was applied at low doses, close to $1 \mathrm{~kg} \mathrm{ha}^{-1}$, for almost all variables, except for RL that obtained the maximum point at $5.2 \mathrm{~kg} \mathrm{ha}^{-1}$.

Studies reported by Mendonça et al. (2006) evaluating the quality of yellow passion fruit seedlings produced in different substrates and fertilized with $L$. calcareum showed that the use of this seaweed at doses up to $4.5 \mathrm{~kg} \mathrm{~m}^{-3}$ was efficient in the development of yellow passion fruit seedlings. However, the authors observed that high doses of L. calcareum resulted in decaying effects on seedlings. Here, the high doses of Lit CS resulted in decaying effect on the initial growth of melon in shoot variables (Figs. 1A and 1C), but it was efficient in root variables (Figs. 1B, 1D, 1E). Such results can be explained as due to the short time of this experiment, and it is possible that a high dose of the product may have caused a phytotoxicity to the seedling, reflecting directly in its growth.

There is an ideal relationship between soil nutrients, as well as $\mathrm{K}, \mathrm{Ca}$ and $\mathrm{Mg}$ cations. When the proportion of these nutrients is greater than indicated, it the manifestation of a nutrient deficiency can occur, as well as the reduction of its absorption by the plant (Zambolim et al., 2012). 


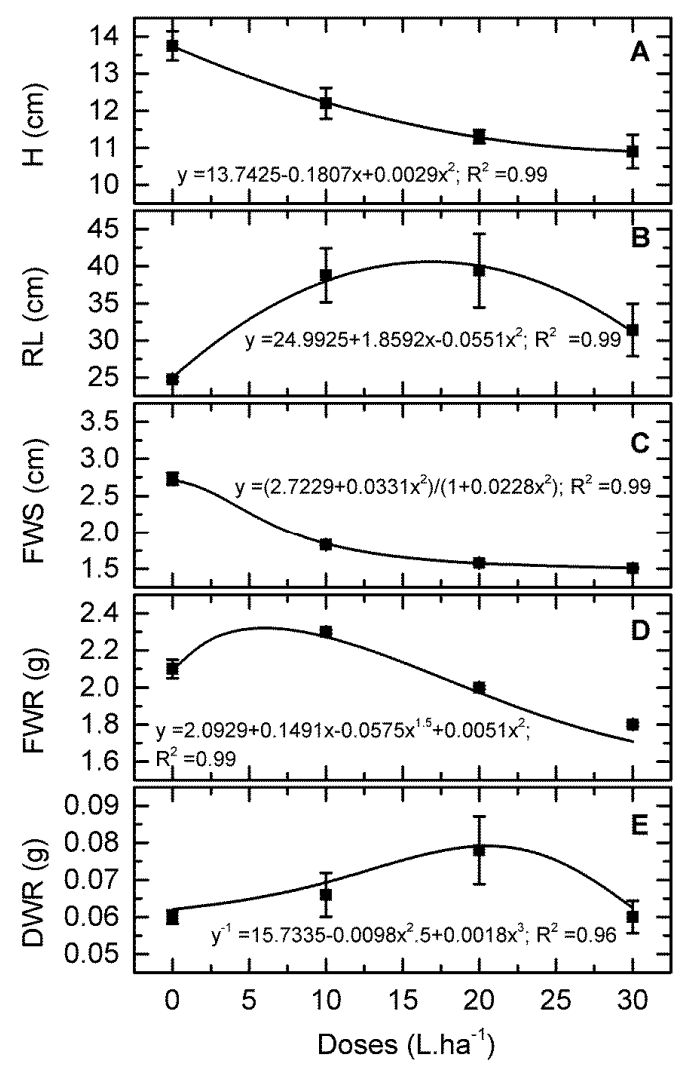

Fig. 1. Plant height $(\mathrm{H})$, shoot fresh matter (SFM), root length (RL), root fresh matter (RFM) and root dry matter (RDM) of melon plants treated with different doses of Lithothamnium calcareum as a concentrated suspension

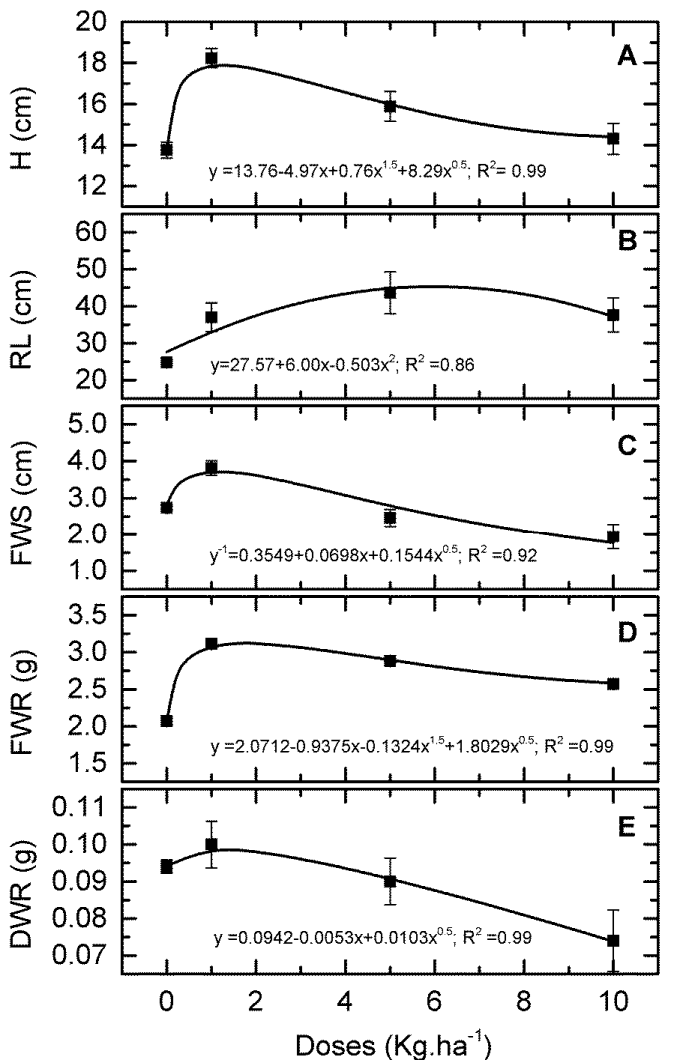

Fig. 2. Plant height $(\mathrm{H})$, shoot fresh matter (SFM), root length (RL), root fresh matter (RFM) and root dry matter (RDM) of melon plants treated with different doses of Lithothamnium calcareum in a nanoparticle formulation

Table 1. Estimation of treatment contrasts to plant height $(\mathrm{H})$, shoot fresh matter (SFM), root length (RL), root fresh matter (RFM) and root dry matter (RDM) of melon plants, submitted to different formulations of Lithothamnion calcareum (Lit)

\begin{tabular}{|c|c|c|c|c|c|c|c|c|}
\hline \multirow{2}{*}{ Variables } & \multicolumn{4}{|c|}{ F values } & \multicolumn{4}{|c|}{ Group means } \\
\hline & $\hat{y}_{1}{ }^{1}$ & $\hat{\hat{y}_{2}}$ & $\hat{\hat{y}_{3}}$ & $\hat{\hat{y}_{4}}$ & Control & $\mathrm{CS}$ & Nano & PM \\
\hline $\mathrm{H}(\mathrm{cm})$ & $11.13^{\circ}$ & $134.52^{\circ}$ & $0.014^{\text {ns }}$ & $69.19^{\circ}$ & 11.70 & 11.47 & 16.14 & 14.00 \\
\hline $\mathrm{SFM}(\mathrm{g})$ & $0.66^{\mathrm{ns}}$ & $30.55^{\circ}$ & 19.26 & $0.23^{\text {ns }}$ & 2.11 & 1.64 & 2.83 & 3.27 \\
\hline $\mathrm{RL}(\mathrm{cm})$ & $4.39^{\circ}$ & $0.81^{\mathrm{ns}}$ & $14.65^{\circ}$ & $19.94^{\circ}$ & 27.00 & 36.53 & 39.40 & 31.80 \\
\hline RFM (g) & $105.19^{\circ}$ & $1731.30^{\circ}$ & $10.72^{\circ}$ & $683.67^{\circ}$ & 2.18 & 2.09 & 2.85 & 2.17 \\
\hline RDM (g) & $0.29^{\mathrm{ns}}$ & $121.04^{\circ}$ & $136.17^{\circ}$ & $378.28^{\circ}$ & 0.07 & 0.06 & 0.09 & 0.04 \\
\hline
\end{tabular}

$\hat{\mathrm{y}}_{1}=$ control vs other treatments; $\hat{y}_{2}=$ Lit. concentrated suspension (CS) vs Lit. nanoparticles (Nano). $\hat{y}_{3}=$ Lit. CS vs Lit. powder-micronized (PM). $\hat{y}_{4}=$ Lit . Nano vs Lit. PM.

${ }^{*}$ Significant at $5 \%$ probability; ns = no significant.

Experiment II: Growth of melon in different formulations and application intervals of $L$. calcareum

The application of different formulations and forms of application of $L$. calcareum did not present significant effects on the initial growth of melon, using the Tukey test $(\mathrm{P}<0.05)$. However, in unfolding, a difference was observed for the RFM variable, which, for an application interval at seven days $(42.58 \mathrm{~g})$, was superior in relation to the other treatments (Table 2).

The different formulations of the applied of $L$. calcareum followed the same pattern as the previous experiment, because the Lit nano was the most efficient treatment on melon growth compared to Lit CS and Lit
PM (Table 2). Although there is no information in the literature on the effect of Lit nanoparticles on the growth of melon, it is suggested that the fractionation of this in nanoparticles increased the contact surface of the product with the root system in relation to the other formulation. This probably provided a higher solubilization and absorption of the nutrients by the roots of the seedlings, thus resulting in a greater development of these.

Melon plants that received Lit nano formulation showed superior results when compared to the PM and CS formulations, with application intervals of seven (7) days, for both SFM and RDM variables. However, the application of fourteen (14) days presented better SFM with the CS formulation $(8.0 \mathrm{~g})$. Regarding the growth of 
430

the root system, it was seen that Lit nano with application an interval of ten (10) days was superior (Table 3 ).

Studies conducted by Melo and Furtini Neto (2003) with the use of $L$. calcareum fertilizer as a corrective of soil acidity and source of nutrients for the common bean (Phaseolus vulgaris L.), concluded that the use of Lit promotes an increase in growth and production of beans plants. These results suggest that $L$. calcareum interacts, exerting a corrective action of the acidity of the substrate, improving the assimilation of the fertilizing elements, as well as favoring the development of the roots and aerial parts of the plants. Here, the application of Lit nano with an application interval of seven (7) days was the most efficient for increasing melon growth.

Table 2. Plant height (H), shoot fresh matter (SFM), root length (RL), root fresh matter (RFM) of melon plants, submitted to different formulations (FL) and forms of application (FA) of Lithothamnion calcareum (Lit)

\begin{tabular}{|c|c|c|c|c|}
\hline FA (days) & $\mathrm{H}(\mathrm{cm})$ & $\mathrm{RL}(\mathrm{cm})$ & SFW (g) & RFW (g) \\
\hline $7+7+7+7$ & $56.73 a$ & $12.93 \mathrm{a}$ & $54.16 a$ & $42.58 \mathrm{a}$ \\
\hline $10+10+10$ & $57.44 \mathrm{a}$ & $13.41 \mathrm{a}$ & $59.58 \mathrm{a}$ & $30.83 \mathrm{~b}$ \\
\hline $14+14$ & $60.14 a$ & $12.62 \mathrm{a}$ & $56.50 \mathrm{a}$ & $33.08 \mathrm{~b}$ \\
\hline $\mathrm{FL}^{1}$ & $\mathrm{H}(\mathrm{cm})$ & $\mathrm{RL}(\mathrm{cm})$ & SFW (g) & RFW (g) \\
\hline Nano & $65.91 \mathrm{a}$ & $15.83 \mathrm{a}$ & $62.91 \mathrm{a}$ & $34.75 a$ \\
\hline PM & $47.69 \mathrm{~b}$ & $9.96 \mathrm{~b}$ & $49.41 \mathrm{~b}$ & $36.25 a$ \\
\hline CS & $60.71 \mathrm{a}$ & $13.16 \mathrm{ab}$ & $57.91 \mathrm{a}$ & $35.50 \mathrm{a}$ \\
\hline
\end{tabular}

Tukey test.

Table 3. Shoot dry matter (SDM) and root dry matter (RDM) of melon plants, submitted to different formulations (FL) and forms of application (FA) of Lithothamnion calcareum (Lit)

\begin{tabular}{|c|c|c|c|c|c|c|}
\hline & \multicolumn{3}{|c|}{$\operatorname{SDM}(\mathrm{g})$} & \multicolumn{3}{|c|}{ RDM (g) } \\
\hline $\begin{array}{l}\text { FA } \\
F^{1}\end{array}$ & $7+7+7+7$ & $10+10+10$ & $14+14$ & $7+7+7+7$ & $10+10+10$ & $14+14$ \\
\hline Nano & $7.10 \mathrm{aA}$ & $6.91 \mathrm{bA}$ & $6.63 \mathrm{cB}$ & $0.82 \mathrm{aA}$ & $0.82 \mathrm{aA}$ & $0.77 \mathrm{aB}$ \\
\hline PM & $5.77 \mathrm{aB}$ & $5.44 \mathrm{bB}$ & $5.44 \mathrm{bC}$ & $0.29 \mathrm{aC}$ & $0.31 \mathrm{aC}$ & $0.28 \mathrm{aC}$ \\
\hline CS & $5.65 \mathrm{cC}$ & $6.97 \mathrm{bA}$ & $8.02 \mathrm{aA}$ & $0.57 \mathrm{bB}$ & $0.51 \mathrm{cB}$ & $1.10 \mathrm{aA}$ \\
\hline
\end{tabular}

${ }^{\mathrm{T}}$ Nano= Nanoparticles; PM= Powder-micronized; CS= Concentrated suspension.

${ }^{*}$ Different lowercase letter in horizontal and uppercase in vertical indicate significant differences $(\mathrm{P}<0.05)$ by ANOVA followed by Tukey test.

\section{Conclusions}

Results presented here are important in understanding how the use of natural algae influences melon growth and highlighting the benefits of $L$. calcareum as an alternative source of fertilizer. The application of $L$. calcareum clearly demonstrates the increase of initial growth of melon plants. In addition, application of $L$. calcareum in nanoparticle formulation in four applications every 7 days were more efficient in the plant growth development. We provide the first report about the use of of $L$. calcareum as an alternative source for fertilization of melon grown in red-yellow soil, and show the beneficial effect of different formulations, application intervals, and doses of $L$. calcareum. These data may be used as reference for future studies with different plants, as well as in the field and for longer periods.

\section{Acknowledgements}

The authors thank the Conselho Nacional de Desenvolvimento Científico e Tecnológico (CNPq) for the financial support given for the accomplishment of the present study.

\section{References}

Alvares CA, Stape JL, Sentelhas PC, Gonçalves JLM, Sparovek G (2013). Köppen's climate classification map for Brazil. Meteorologische Zeitschrift 22:711-728.
Araújo POLC, Gonçalves FC, Ramos JD, Chalfun NNJ, Carvalho GJ (2007). Growth and percentage of emergence of citrumeleiro "Swingle" seedlings in relation to substrates and doses of Lithothamnium based correctives, after a hundred days from 'Swingle'. Ciência e Agrotecnologia 31:982-988.

Carlos AC, Sakomura NK, Pinheiro SRF, Toledano FMM, Giacometti R, Silva Júnior JW (2011). Use of algae Lithothamnium calcareum as alternative source of calcium in diets for broiler chickens. Ciência e Agrotecnologia 35:833-839.

Cavalcanti VMM (2011). Plataforma Continental: A última fronteira da mineração brasileira [Continental Shelf: The last frontier of Brazilian mining]. Departamento Nacional de Produção Mineral, Brasilia, Brazil.

Costa AC, Ramos JD, Silva FOR, Menezes TP, Moreira RA, Duarte MH (2015). Organic fertilizer and Lithothamnium on the cultivation of red pitaya. Semina: Ciências Agrárias 36:77-88.

Costa Neto JM, Teixeira RG, Sá MJC, Lima AE, Jacinto-Aragão GS, Teixeira MW, Martins Filho EF, Toribio JMML, Azevedo AS (2010). Seaweed flour ("Lithothamnium calcareum") as a mineral supplement in the bone healing of a cortical autograft in dogs. Revista Brasileira de Saúde e Produção Animal 11:217-230.

Cruz MCM, Hafle O, Ramos JD, Ramos OS (2008). Development of tangerine tree rootstock 'Cleópatra'. Revista Brasileira de Fruticultura 30:471-475.

Dias GTM (2000). Granulados bioclásticos - algas calcárias [Marine Bioclasts - Calcareous Algae]. Revista Brasileira de Geofisica 18:307-318. Evangelista AWP, Alves Júnior J, Melo PC (2013). Response of coffee crop 
to irrigation levels and fertilization with Alfertil. Revista Brasileira de Engenharia Agrícola e Ambiental 17:392-396.

Filgueira FAR (2008). Novo Manual de Olericultura: agrotecnologia moderna na produção e comercialização de hortaliças [New Manual of Olericultura: modern agro-technology in the production and commercialization of vegetables]. Universidade Federal de Viçosa, Viçosa, Brazil.

Goetz P (2008). Phytothérapie del'ostéoporose. Phytothérapie 6:33-38.

Graham JE, Wilcox LW, Graham LE (2008). Algae. Benjamin Cummings: San Francisco, USA.

Guiry MD, Guiry GM (2017). AlgaeBase. World-wide electronic publication. National University of Ireland, Galway. Retrieved September 13,2017 from http://www.algaebase.org.

Hafle OM, Santos VA, Ramos JD, Cruz MCM, Melo PC (2009). Production of seedlings of papaya tree using Bokashi and Lithothamnium. Revista Brasileira de Fruticultura 31:245-251.

Hagg FM, Erasmus LJ, Van der Veen RH, Haasbroek E, Taylor Oguey C (2013). Phytonutrients or calcified marine algae as natural alternatives to monensin in beeffeedlot diets. Journal of Animal Science 91:138.

Kempf M (1974). Perspectives d'exploitation des fonds de maerl du Plateau Continental du NE du Brésil [Prospects for Exploitation of maerl funds from the Continental Shelf NE of Brazil]. II Coll. Intern. Exploitation des Oceans. Bordeaux, France2.

Le Bleu P (1983). Contribution à l'étude des algues marines en Bretagne: bilan de leur utilisation en milieu agricole [Contribution to the study of marine algae in Brittany: assessment of their use in agriculture]. France, Tours.

Lopes NM, Pereira RAN, Pereira MN (2013). Intake, milk yield, and blood acid-base balance of cows in response to marine algae meal. Journal of Animal Science 91:29.

Melo PC, Furtini Neto AE (2003). Evaluation of Lithothamnium as corrective of soil acidity and source of nutrients for bean plants. Ciência e Agrotecnologia 27:508-519.

Mendonça V, Orbes MY, Abreu NAA, RamosJD, Teixeira GA, SouzaHA (2006). Quality of yellow passion fruit formatted in substrate with different level of Lithothamniun. Ciênciae Agrotecnologia 30:900-906.

Santos HG, Jacomine PKT, Anjos LHC, Oliveira VA, Lumbreras JF,
Coelho MR, Almeida JAC, Cunha TJF, Oliveira JB (2013). Sistema brasileiro de classificação de solos [Brazilian system of soil classification]. Empresa Brasileira de Pesquisa Agropecuária (3th ed), Brasilia, Brazil.

Schlegel P, Gutzwiller A (2017). Effect of dietary calcium level and source on mineral utilization by piglets fed diets containing exogenous phytase. Journal of Animal Physiology and Animal Nutrition 101:165-174.

Silva FAS, Azevedo CAV (2016). The Assistat Software Version 7.7 and its use in the analysis of experimental data. African Journal of Agricultural Research 11:3733-3740.

Souza HA, Mendonça V, Ramos JD, Ferreira EA, Alencar RD (2007). Doses de Lithothamnium e diferentes substratos na produção de mudas de maracujazeiro 'doce' [Substrates composition and Lithothamnium in the production of 'sweet' passion fruit seedlings]. Revista Caatinga 20:2430.

Teixeira GA, Souza HA, Mendonça V, Ramos JD, Chalfun NNJ, Ferreira E, Melo PC (2009). Produção de mudas de mamoeiro 'formosa' em substratos com doses de Lithothamnium [Production of papaya changes in substrates with Lithothamnium]. Revista da Faculdade de Zootecnia, Veterinária e Agronomia 16:220-229.

Thangavelu K, Subramani KB (2016). Sustainable biopolymer fibers production, properties and applications. In: Muthu SS, Gardetti M (Eds). Sustainable Fibres for Fashion Industry. Springer Singapore pp 109-140.

Ucrós NS, Ferreira WM, Torres RCS, Borges NF, Silveira SS, Rezende CMF (2012). Lithothamnium calcareum no tratamento de osteotomia experimental em coelhos (Oryctolagus cuniculus) [Lithothamnium calcareum in the treatment of experimental osteotomy: In rabbits (Oryctolagus cuniculus)]. Arquivo Brasileiro de Medicina Veterinária e Zootecnia 64:615-622.

Woelkerling WJ (1985). Proposal to Conserve Lithothamnion against Lithothamnium (Rhodophyta: Corallinaceae). Taxon 34:302-303.

Zambolim L, Ventura JA, Zanão Júnior LA (2012). Efeito da nutrição mineral no controle de doenças de plantas [Effect of mineral nutrition on the control of plant diseases]. Universidade Federal de Viçosa (1st ed), Viçosa, Brazil. 